\title{
Modest Amyloid Deposition is Associated with Iron Dysregulation, Microglial Activation, and Oxidative Stress
}

\author{
Joseph J. Gallagher ${ }^{\mathrm{a}, *}$, Mary E. Finnegan ${ }^{\mathrm{b}}$, Belinda Grehan ${ }^{\mathrm{a}}$, Jon Dobson ${ }^{\mathrm{c}, \mathrm{d}}$, \\ Joanna F. Collingwood ${ }^{\mathrm{b}, \mathrm{c}}$ and Marina A. Lynch ${ }^{\mathrm{a}}$ \\ ${ }^{\mathrm{a}}$ Department of Physiology, Trinity College Institute of Neuroscience, Trinity College Dublin, Dublin, Ireland \\ ${ }^{\mathrm{b}}$ School of Engineering, University of Warwick, Coventry, UK \\ ${ }^{\mathrm{c}}$ Institute of Science and Technology in Medicine, Keele University, Stoke-on-Trent, UK \\ ${ }^{\mathrm{d}}$ Departments of Biomedical Engineering and Materials Science and Engineering, University of Florida, \\ Gainesville, Florida, USA
}

Handling Associate Editor: Jane Flinn

Accepted 24 August 2011

\begin{abstract}
There is a well-established literature indicating a relationship between iron in brain tissue and Alzheimer's disease (AD). More recently, it has become clear that $\mathrm{AD}$ is associated with neuroinflammatory and oxidative changes which probably result from microglial activation. In this study, we investigated the correlative changes in microglial activation, oxidative stress, and iron dysregulation in a mouse model of $\mathrm{AD}$ which exhibits early-stage amyloid deposition. Microfocus X-ray absorption spectroscopy analysis of intact brain tissue sections prepared from A $\beta P P / P S 1$ transgenic mice revealed the presence of magnetite, a mixed-valence iron oxide, and local elevations in iron levels in tissue associated with amyloid- $\beta$-containing plaques. The evidence indicates that the expression of markers of microglial activation, CD11b and CD68, and astrocytic activation, GFAP, were increased, and were histochemically determined to be adjacent to amyloid- $\beta$-containing plaques. These findings support the contention that, in addition to glial activation and oxidative stress, iron dysregulation is an early event in AD pathology.
\end{abstract}

Keywords: Alzheimer's disease, iron, microglia, oxidative stress, spectrometry, X-ray fluorescence

\section{INTRODUCTION}

Iron plays a pivotal role in many physiological processes, for example in the transport of oxygen, electron transport, and in the synthesis of certain neurotransmitters [1]. Intracellular iron is stored in the cytosolic protein ferritin, a $12 \mathrm{~nm}$ diameter 24-subunit protein shell encasing a hollow interior capable of containing

${ }^{*}$ Correspondence to: Joseph J. Gallagher, Biological Imaging Centre, Beckman Institute, m/c 139-74, California Institute of Technology, Pasadena, California, USA. Tel.: 1626395 2004; Fax: 626449 5163; E-mail: jjg@ caltech.edu. a maximum of approximately 4,500 iron atoms. Iron is normally taken up from the redox active $\mathrm{Fe}^{2+}$ state and converted to the less reactive ferric $\left(\mathrm{Fe}^{3+}\right)$ valence state in a ferrihydrite-like hydrated iron oxide [2]. Nonheme iron circulates in the blood mainly in a tight, but reversible, bond with the glycoprotein, transferrin. Blood brain barrier endothelial cells express a specific transferrin receptor (TfR) which facilitates cellular internalization of iron [3]. Ferritin, brain endogenous transferrin and TfR are heterogeneously expressed in different brain cell types and brain regions which further complicates a currently poor understanding of iron release into the brain and its subsequent regulation 
[4]. Recent work has identified that alterations in iron metabolism, due to mutations in genes encoding iron metabolism-related proteins in disorders such as Friedreich's ataxia and neuroferritinopathy, lead to a wide range of debilitating behavioral deficits which are associated with neuronal degeneration $[5,6]$.

Considerable evidence supports the role of amyloid$\beta(A \beta)$ in the pathogenesis of Alzheimer's disease (AD) [7] and more recent evidence has identified soluble forms of $A \beta$ as the potential progenitor of several pathological aspects of $\mathrm{AD}$ [8]; these include mitochondrial abnormalities [9], deficits in axonal transport [10], alterations in synaptic density [11] and, most interestingly in the context of this study, widespread oxidative stress $[12,13]$ and robust, persistent microglial activation [14, 15]. Several reports propose that oxidative stress is one of the earliest changes in AD pathogenesis [16, 17]. Complementary work indicating that soluble $A \beta$ triggers microglial activation [18], and that activated microglia which stain positively for inflammatory cytokines [19] are recruited to newly formed $A \beta$ plaques [20], suggest these two processes may be integral to subsequent pathology progression.

A long-standing link between aberrant accumulation of iron in the central nervous system (CNS) and neurodegenerative disorders such as AD exists [21]. Reports identifying the presence of iron, copper, and zinc in Aß-containing plaques [22-24], in addition to alterations in histochemically-identified patterns of ferritin and transferrin proximal to plaques [25] in end-stage human $\mathrm{AD}$ brain tissue, suggest iron accumulation and/or dysregulation may be pathogenic in AD. Recent work has indicated that iron concentrations and redox-active iron were elevated in postmortem brain tissue from patients diagnosed with mild cognitive impairment (MCI), the probable clinical precursor to $\mathrm{AD}$, which is suggestive of dysregulation [26].

The predominant iron oxide in human brain tissue is ferrihydrite-like as found in ferritin cores; in addition there is some evidence of iron oxide deposition as haemosiderin, where the mineral form in tissues is often observed to be goethite-like. Experimental work has demonstrated the presence of another form of iron oxide, biogenic magnetite $\left(\mathrm{Fe}_{3} \mathrm{O}_{4}\right)$, in human brain tissue. This form contains alternating lattices of ferrous and ferric ions and was first isolated from human brain tissue by Kirschvink and co-workers [27]. This finding has been replicated in several subsequent magnetometry studies, utilizing the differences in magnetic properties between magnetite and the iron oxides normally found in brain tissue [28]. Recent advances in the application of microfocus X-ray absorption spectroscopy ( $\mu \mathrm{XAS}$ ) have enabled in situ localization and characterization of magnetite deposits in cortical senile-plaque-rich AD brain tissue [29]. Electron microscopy techniques have also confirmed the presence of iron oxides with the crystalline properties of magnetite in isolated $A \beta$ plaque cores [30, 31], and an increased fraction of magnetite in ferritin from the postmortem brain of individuals with $\mathrm{AD}$ and supranuclear palsy [31]. It has been hypothesized that the formation of biogenic magnetite may be associated with elevated levels of $\mathrm{Fe}^{2+}$ where the latter may stimulate excess production of tissue-damaging free radicals [ 32 , 33]. Furthermore, it has been shown in vitro that in neutral oxygenated buffer, under conditions where $\mathrm{Fe}^{2+}$ auto-oxidizes to $\mathrm{Fe}^{3+}$, a proportion of the iron is stabilized as $\mathrm{Fe}^{2+}$ in the presence of aggregating $\mathrm{A} \beta_{42}$ [34].

In this study we investigated the presence of various iron oxide forms, and combined this with analysis of microglial activation and oxidative stress, in tissue prepared from a mouse model of AD which exhibits early-stage amyloid deposition. This mouse is engineered to overexpress the Swedish mutation of human amyloid- $\beta$ protein precursor (A $\beta P$ ) and presenilin 1 (PS1). Our findings support the hypothesis that iron dysregulation, as determined by $\mu$ XAS analysis of brain tissue prepared from a mouse model of $\mathrm{AD}$, is an early event in $\mathrm{AD}$ pathogenesis and is associated with microglial activation, oxidative stress and early-stage $\mathrm{A} \beta$ deposition.

\section{METHODS}

\section{Animals}

Specific pathogen-free (SPF) C57BL/6 mice were purchased from Harlan UK Ltd. (Bicester, UK). Transgenic animals from an existing colony of A $\beta$ PPswe/PS1dE9 transgenic mice (hereafter referred to as $\mathrm{A} \beta \mathrm{PP} / \mathrm{PS} 1$ transgenic mice), purchased from The Jackson Laboratory (Maine, USA), were used to form breeding pairs with the C57BL/6 mice and bred in an SPF animal housing facility in the Bioresources Unit, Trinity College, Dublin. Mice were maintained according to the regulations and guidelines provided by the local ethical committee. All animals were housed under a 12-h light-dark cycle at an ambient temperature of $22^{\circ} \mathrm{C}-23^{\circ} \mathrm{C}$ and were maintained under veterinary supervision throughout. Normal laboratory chow and water were freely available to all animals. Female mice, aged 8-9 months, were used in this study. Animal experimentation was performed under a 
license granted by the Minister for Health and Children (Ireland) under the Cruelty to Animals Act 1876 and the European Community Directive, 86/609/EEC, and every effort was made to minimize animal stress.

\section{Surgical equipment and surface metal-particulate decontamination}

Ceramic forceps, ceramic tweezers, and a sapphire cryosectioning blade (Electron Microscopy Services, USA) were acid-washed $(3 \% \mathrm{HCl})$ and rinsed in deionized water. All surfaces were plastic, acid-washed $(3 \% \mathrm{HCl})$, and rinsed in de-ionized water prior to use. All containers with reagents were placed on $\mathrm{NdFeB}$ bar magnets and, to ensure that magnetic contaminants were removed and, as a further precaution to avoid magnetic particulate contamination, reagents were always pipetted from the top of the containers.

\section{Intracardial perfusion}

All A $\beta P P / P S 1$ transgenic and wildtype mice used in this study were anaesthetized with an i.p., injection of sodium pentobarbital ( $30 \mu$ l, Euthanol, Merial Animal Health, UK); the absence of the toe-pinch reflex was indicative of deep anesthesia. Intra-cardial perfusion was performed for $20 \mathrm{~min}$ using $0.1 \mathrm{M}$ sodium cacodylate (Sigma-Aldrich, UK) which avoided the introduction of extraneous phosphates and the possibility that they might chelate trace metals of interest from the tissue. The brain was removed using ceramic tweezers and forceps and processed as required. Following brain dissection the intact brain was cut using a sapphire blade and the right hemisphere used for SQuID magnetometry and subsequent ICP-MS analysis. The left hemisphere was retained for molecular, immunohistochemical, and fluorescence analysis.

\section{Immunohistochemistry}

A $\beta$-containing plaques were visualized using Congo red staining [35]. Briefly, air-dried coronal cryostat sections $(15 \mu \mathrm{m})$, obtained from tissue mounted on cork and flash frozen in OCT (Tissue-Tek, Finland), were fixed in ice-cold ethanol for $10 \mathrm{~min}$, washed twice with phosphate-buffered saline (PBS), incubated in an alkaline $\mathrm{NaCl}$ solution for $20 \mathrm{~min}$ and incubated in a filtered alkaline Congo red solution for $30 \mathrm{~min}$ at room temperature. Sections were rinsed in $\mathrm{ddH}_{2} \mathrm{O}$ for $30 \mathrm{~s}$ and counterstained for $1 \mathrm{~min}$ in a $1 \%(\mathrm{w} / \mathrm{v})$ methylgreen solution (Sigma-Aldrich, UK). Excess staining solution was removed by washing in $\mathrm{ddH}_{2} \mathrm{O}$ for $1 \mathrm{~min}$ and sections were dehydrated through a graded alcohol series (75\%, 95\%, 100\%; Sigma, UK). Sections were air-dried and placed in 3 separate xylene baths for $5 \mathrm{~min}$ each. Coverslips were placed onto DPX (RA Lamb, UK) covered sections and left to dry in a fume hood for $24 \mathrm{~h}$. For double staining, Congo red-stained sections were washed 3 times with $\mathrm{ddH}_{2} \mathrm{O}$ prior to dehydration ( $5 \mathrm{~min} /$ wash). Congo-red stained $\mathrm{A} \beta$-plaques were counted on coronal brain sections containing the hippocampus ( $n=4$ sections were counted per animal) to determine the average plaque count per brain section ( $n=4$ mice were assessed).

Immunohistochemical assessment of CD68 expression was performed using the avidin-biotinperoxidase complex reaction in Tris-buffered saline (TBS, pH 7.5). Non-specific interactions were blocked by incubation in TBS (4\% bovine serum albumin (BSA); Sigma, UK, 10\% normal goat serum (NGS); Vector, UK), for $30 \mathrm{~min}$ at room temperature. Sections were incubated overnight in rabbit anti-CD68 antibody solution (1/200 Santa Cruz Biotechnology, US; in $2 \% \mathrm{BSA}$ in TBS), washed in TBS, incubated in biotin-conjugated goat anti-rabbit secondary antibody, (Vector, UK; $1 / 200$ in $2 \%$ BSA in TBS) for $2 \mathrm{~h}$ at room temperature and washed. To block endogenous peroxidases, sections were incubated in $0.3 \% \mathrm{H}_{2} \mathrm{O}_{2}$ in TBS for $15 \mathrm{~min}$ and after washing were incubated in a pre-made avidin solution. To develop color, washed sections were incubated in diaminobenzidine (DAB solution, $0.06 \% \mathrm{H}_{2} \mathrm{O}_{2}$; Vector, $\mathrm{UK}$ ) for $10 \mathrm{~min}$. Sections were washed, dehydrated through a series of graded alcohols (75\%, 95\%, 100\%; Sigma, UK), and cleared by immersion in xylene (Sigma, UK). Coverslips were applied using DPX (RA Lamb, UK) as the mount, and slides were left overnight to set in a fume hood.

Immunoreactivity of 8-hydroxy-2' deoxyguanosine (8-OHdG), which assesses oxidative damage to DNA and RNA, was used as a proxy marker of oxidative stress. Sections were washed in ice-cold methanol, rinsed in TBS buffer ( $\mathrm{pH} 7.4$ ) and incubated sequentially in $4 \% \mathrm{HCl}$ for $7 \mathrm{~min}$, and in $50 \mathrm{mmol} / \mathrm{L}$ Tris base (denaturation and neutralization respectively). Sections were incubated for $30 \mathrm{~min}$ at room temperature in $10 \%$ normal horse serum (Vector, UK) and 4\% BSA (Sigma, UK) in TBS, to block nonspecific interactions and then incubated (overnight at $4{ }^{\circ} \mathrm{C}$ ) in goat anti-8-OHdG antibody (1/1000 in $2 \%$ BSA; Abcam, UK). Sections were rinsed, and incubated in biotin-conjugated horse anti-goat antibody (1/200 in $2 \%$ BSA in TBS; (Vector, UK)), rinsed, incubated in $0.3 \% \mathrm{H}_{2} \mathrm{O}_{2}$ in TBS for $15 \mathrm{~min}$ and washed. Sections 
were incubated in avidin-biotinylated peroxidase complex solution (ABC kit, Vector, UK) for $1 \mathrm{~h}$ and $\mathrm{DAB}$ solution (Vector, $\mathrm{UK} ; 2 \mu \mathrm{H} \mathrm{H}_{2} \mathrm{O}_{2} / \mathrm{mL}$ ) was applied for $10 \mathrm{~min}$. Sections were rinsed in distilled water, dehydrated through a series of graded alcohols $(75 \%, 95 \%$, $100 \%$; Sigma, UK), cleared in xylene, and mounted in DPX (RA Lamb, UK) and left to set overnight in a fumehood.

Air-dried cryostat sections $(15 \mu \mathrm{m})$ prepared from the brains of A $\beta P P / P S 1$ transgenic and wildtype mice were assessed for $A \beta$ immunoreactivity. To permeabilize the tissue, sections were fixed in ice-cold methanol for $10 \mathrm{~min}$, washed in PHEM, PHEM containing $0.1 \%$ Triton (Sigma-Aldrich, UK) and again in PHEM. Nonspecific binding was blocked by incubating samples in $4 \%$ BSA containing $10 \%$ NGS for $2 \mathrm{~h}$ at room temperature. Sections were incubated in the presence of the primary antibody $\left(1: 1000\right.$, Pan-Amyloid $\left(\mathrm{A} \beta_{42}\right)$ antibody, Calbiochem, US) in 2\% BSA containing 5\% NGS overnight at $4{ }^{\circ} \mathrm{C}$, washed in PHEM and incubated in the presence of the secondary antibody $(1: 4000$ in $2 \%$ BSA containing 5\% NGS; $90 \mathrm{~min}$ at room temperature; ALEXA 488, Invitrogen, US). The sections were washed, mounted with DAPI-containing mounting medium (Vectashield, Vector Labs, USA), dried for $24 \mathrm{~h}$ and visualized by confocal microscopy (Axioplan 2 , Zeiss, Germany). In some cases, $A \beta$-stained sections were washed and the staining process repeated with a primary antibody for MHC II (1 : 1000, MHC II antibody, Calbiochem, US) as previously described [36].

\section{$m R N A$ analysis $(C D 11 b, C D 68, I L-1 \beta$,} and GFAP $m R N A)$

RNA was extracted from CNS tissue, encompassing the hippocampus and cortex, using a NucleoSpin RNAII isolation kit (Macherey-Nagel, Germany) according to the manufacturer's instructions. RNA concentrations were equalized to $1 \mu \mathrm{g}$ before cDNA synthesis using a High Capacity cDNA RT Kit (Applied Biosystems, Germany) according to the manufacturer's protocol. Equal concentrations of cDNA were used for Real-time (RT)-PCR amplification. RT-PCR primers were delivered as "Taqman ${ }^{\circledR}$ Gene Expression Assays" as previously described [37], and the assay IDs for the genes assessed were: CD11b (Mm01271263_m1), CD68 (Mm03047343_m1), IL-1ß (Mm00434288_m1), and GFAP (Mm01253033_m1). Target gene expression was calculated relative to the endogenous control ( $\beta$-actin) to give a relative quantification (RQ) value ( $2^{-\mathrm{DDCT}}$, where CT is threshold cycle).
SQuID magnetometry

All equipment and surfaces used in this procedure were treated to remove metal particulate contamination as outlined above. Tissue was prepared for SQuID magnetometry as previously described [38]. Following freeze-drying, a single wildtype sample was removed from the study as it exhibited a $45 \%$ decrease in weight, compared with $77 \pm 5.2 \%$ for all other samples. Samples were fragmented using a sapphire blade and tightly packed into the centre of a SQuID sample straw (Quantum Design, CA, USA) using custommade non-metallic presses and assessed using a MPMS 7 SQuID magnetometer (Quantum Design, CA, USA). A sample degaussing sequence was carried out at $300 \mathrm{~K}$, and then the isothermal remanent magnetization (IRM) was measured at $5 \mathrm{~K}$ and $150 \mathrm{~K}$ following exposure to a field of 1 Tesla; this field is sufficient to saturate magnetite ensuring the IRM at $150 \mathrm{~K}$ is dominated by magnetite as ferrihydrite contributes to IRM at $5 \mathrm{~K}$ only. Eight measurements of the IRM were obtained directly after the field had been removed, and the last five measurements (where the initial decay had stabilized) were averaged to obtain the IRM value for each sample. A negative control containing no sample was prepared, assessed using an identical protocol, and used for blank subtraction purposes.

\section{ICP-MS}

The samples analyzed using SQuID magnetometry were assessed for metal content using an Varian 820 ICP-MS (Varian, USA). A known weight of each sample was digested in a 7:1 ratio of $69 \% \mathrm{HNO}_{3}$ and $35 \% \mathrm{H}_{2} \mathrm{O}_{2}$ heated to $200^{\circ} \mathrm{C}$ at $1000 \mathrm{~W}$ for $20 \mathrm{~min}$ (EZ digester; Milestone Scientific, US) and brought to $50 \mathrm{ml}$ with ultrapure water (Sigma-Aldrich, UK). Data were acquired in peak-hopping mode with 15 scans per replicate and 3 non-consecutive replicates per sample. A sample containing only the digested reagents was used for blank subtraction purposes.

\section{$X$-ray Absorption Spectroscopy analysis}

\section{Tissue preparation}

All equipment and surfaces used in this procedure were treated to remove metal particulate contamination as outlined above. Following brain dissection, coronal cryosections $(50 \mu \mathrm{m})$ from an A $\beta P P / P S 1$ transgenic and wildtype mouse brain were taken using a sapphire cryomicrotome blade (Electron Microscopy Services, USA) on a cryostat (Leica CM1900, Leica Microsystems Inc, USA) that was not used for 2 days beforehand 
to minimize air-borne dust particles. A single section from each animal was placed onto a high quality quartz microscope slide (H Baumbach \& Co. Ltd., UK) and stored at $-80^{\circ} \mathrm{C}$ in a parafilm wrapped slide box. Air-dried cryostat sections were mounted for room temperature microfocus X-Ray Fluorescence ( $\mu \mathrm{XRF}$ ) and microfocus X-ray Absorption Near Edge Spectroscopy ( $\mu$ XANES) analysis. A layer of kapton film ( $25 \mu \mathrm{m}$ thick; Electron Microscopy Services, USA) covered the tissue sections during measurements with an airtight epoxy seal joining the kapton film to the quartz slide.

\section{Microfocus X-Ray Fluorescence ( $\mu X R F)$ acquisition and analysis}

High resolution $\mu$ XRF mapping was carried out on the I18 beamline at Diamond Light Source [39]. Sections were screened for signal from a range of metal elements by measuring $\mu \mathrm{XRF}$ intensity above the K-edge for iron $(7112 \mathrm{keV})$, using a primary beam of $10 \mathrm{keV}$. $\mu$ XRF spectra were captured at a rate of one second per pixel, following stepped sample rastering on an $\mathrm{x}-\mathrm{y}$ stage, with fluorescence signal detected using a high rate fluorescence 9 element Ge solid state detector system. Large area maps were obtained at $60 \mu \mathrm{m}$ resolution and off-site analysis was carried out in the PyMCA software program [40] where data were normalized to incoming beam intensity. Linear combination fitting of the individual fluorescence peaks in each spectrum enabled the contributions from major peaks, including $\mathrm{Fe}, \mathrm{Cu}$, and $\mathrm{Zn}$ to be calculated, and the contributions from smaller peaks (e.g., $\mathrm{Mn}$ ) to be identified. Intensity maps for each element of interest were computed from the fitted spectra, determining signal intensity (and the standard deviation obtained from the fit quality), for the chemical elements in each pixel. In order to allow comparison of relative concentrations of elements between selected areas in a tissue section, the intensity spectrum was normalized to the number of pixels in each selection. Slide regions without tissue were used to obtain the background spectrum, so that this could be subtracted from the main spectra to obtain the true signal from the tissue. Potassium concentration within the brain region under investigation was used to give an approximate indication of sample thickness, as the distribution was more uniform than for the other elements observed, and any potassium in the quartz slide and coverslip was below detection levels. The potassium maps were useful in image analysis and correlation with the light microscopy images, as they allowed features such as folds, tears, and voids in the tissue sections to be clearly identified. Subsequent staining of the sections with Congo red made it possible to compare relative metal ion concentrations in those regions with extensive $\mathrm{A} \beta$ deposition, and those lacking Congo-redpositive material. During the same experiment, areas exhibiting high iron fluorescence were subjected to $\mu \mathrm{XRF}$-mapping at a higher resolution of $5 \mu \mathrm{m}$ (these data were processed as outlined above) and sites within these areas were chosen for $\mu$ XANES analysis (these areas were not viable for Congo-red staining).

\section{Microfocus X-ray Absorption Near Edge \\ Spectroscopy ( $\mu X A N E S)$ acquisition and analysis}

$\mu$ XRF-mapping $(5 \mu \mathrm{m})$ of areas exhibiting high iron fluorescence on the $60 \mu \mathrm{m}$ XRF maps enabled identification of sites exhibiting focal increases in iron fluorescence. These were chosen for $\mu$ XANES characterization and data were obtained through the K-edge from 6960 to $7090 \mathrm{eV}$ in steps of $5 \mathrm{keV}$ with a dwell time of $3 \mathrm{~s}$, from 7090 to $7145 \mathrm{eV}$ in steps of $0.5 \mathrm{keV}$ with a dwell time of $7 \mathrm{~s}$ and from 7145 to $7450 \mathrm{eV}$ in gradually increasing steps of 1.0 to $3.0 \mathrm{keV}$ with a dwell time of $3 \mathrm{~s}$. A single spectrum was taken at each site identified for XANES analysis, with spectra taking approximately $30 \mathrm{~min}$ to acquire. Previous studies utilizing the same experimental protocol and setup have identified unchanged XANES spectra from sites subjected to repeated acquisition; and dispersed nanoparticle iron oxide standards with a variety of redox states have been successfully characterized: in this context, beam induced redox changes are thought to be negligible. A reference trace from an iron foil (positioned well away from the sample) was obtained in parallel with each XANES measurement in order to provide confirmation of the edge energy. $\mu$ XANES data were analyzed using the IFEFFIT Athena software package [38]. Briefly, fluorescence intensity was first normalized to the incident beam intensity at each measured point. Background removal was performed following the standard procedure in Athena, with line regression to the pre-edge range $(-100$ to $-20 \mathrm{eV})$, and polynomial regression to the post-edge range (50 to $350 \mathrm{eV}$ ). The components of each $\mu$ XANES spectrum were fit with a set of standards measured under the same experimental conditions (including ferrihydritecontaining ferritin, haematite, dispersed magnetite nanoparticles, and dispersed maghemite nanoparticles), using Athena's linear combination fitting routine that enables the relative proportions of fitted standards to be compared between spectra [41]. Representative examples of $\mu$ XANES data are presented in Fig. 5, with a subset of the energy range assessed plotted (7080-7180 keV). Subsequent Congo red staining of the areas subjected to $\mu$ XANES and $\mu$ XRF-mapping 
at a resolution of $5 \mu \mathrm{m}$ was not possible due to tissue fragility.

\section{$\mu X A S$ statistical analysis and sampling}

A single coronal brain section, at approximately $-2.30 \mathrm{~mm}$ Bregma, prepared from an 8-9 month old A $\beta P P / P S 1$ transgenic mouse was assessed using $60 \mu \mathrm{m}$-resolution XRF-mapping; tissue subjected to only this analysis was viable for subsequent Congo red staining. Colocalization of areas of iron deposition identified on the $60 \mu \mathrm{m}$ XRF map and congo-red positive staining were identified in the cortex $(n=3)$ and the hippocampus $(n=2)$. These areas were assessed for the relative increase in iron, copper, and zinc by comparison to adjacent regions. Thus normalizing the data to concentration variability due to brain region and cell type; Fig. 4a-d contains a representative example of colocalization in the hippocampus while Fig. 4e presents all colocalization data. Within the same brain section 2 areas (hippocampal CA3 subfield and dorsal retrosplenial cortical regions) were XRF-mapped at a $5 \mu \mathrm{m}$ resolution identifying 4 areas which were then subjected to $\mu$ XANES analysis (these areas were not viable for Congo red staining). To maintain consistency with the $60 \mu \mathrm{m}$ XRF maps obtained from the hippocampus provided in Fig. 4, the data presented in Fig. 5 were obtained from the hippocampal CA3 subfield.

\section{RESULTS}

The total iron concentration and IRM of a single brain hemisphere is not altered by the amyloid deposition associated with 8-9 month old A $\beta P P / P S 1$ transgenic mice

Immunohistochemical assessment of brain sections prepared from 8-9 month old A $\beta P P / P S 1$ transgenic and wildtype mice using Congo red confirmed the presence of $A \beta$-containing plaques (Fig. 1a, b); no plaques were observed in brain sections prepared from wildtype mice. Average plaque number per coronal brain section prepared from transgenic mice was $14.45 \pm 1.6$ per section. This is in line with previous studies at the same timepoint and is modest relative to the extensive levels of deposition reported in older mouse models of $\mathrm{AD}$ [42-44]. No significant change in brain tissue iron concentration was observed in A $\beta P P / P S 1$ transgenic, compared with wildtype, mice (Fig. 1c); copper and zinc concentration were also similar in both groups (data not shown). Analysis of IRM data, obtained from brain tissue prepared from A $\beta P P / P S 1$ transgenic and wildtype mice, revealed no significant differences at $5 \mathrm{~K}$ or $150 \mathrm{~K}$ (Fig. 1d). The signal at $5 \mathrm{~K}$ is predominantly associated with ferrihydrite-like ferritin cores which are usually not blocked above $20-30 \mathrm{~K}$, and the trace signal at $150 \mathrm{~K}$ is only slightly greater than that from the measured blank. The iron concentration and IRM data are in agreement, and no difference between the A $\beta P P / P S 1$ and wildtype mice can be determined on the basis of these bulk measurements.

Modest amyloid deposition is associated with an increase in markers of microglial and astrocytic activation and oxidative stress

Markers of microglial and astrocytic activation were assessed using RT-PCR and the data indicate that the expression of CD11b, CD68, IL-1 $\beta$, and GFAP mRNA was significantly increased in tissue prepared from A $\beta P P / P S 1$ transgenic, compared with, wildtype mice $(* * p<0.01$; *** $p<0.001$; Student's $t$-test for independent means, Fig. 2). Immunohistochemical analysis confirmed microglial activation by revealing increases in MHC II (Fig. 3b) and CD68 (Fig. 3c-e) in tissue prepared from A $\beta P P / P S 1$ transgenic mice compared with wildtype mice. Staining for both markers was enhanced proximal to plaques. Increased $8-\mathrm{OHdG}$ immunoreactivity proximal to $A \beta$-containing plaques was also observed (Fig. 3f); this indicates oxidative damage to DNA and/or RNA and is therefore a marker of oxidative stress. These data demonstrate that A $\beta P P / P S 1$ transgenic mice exhibit neuroinflammatory and oxidative changes at a relatively early age and that these accompany the development of $\mathrm{A} \beta$-containing plaques.

Iron levels are increased in tissue associated with $A \beta$-containing plaques

$\mu \mathrm{XAS}$ spectral analysis was combined with immunohistochemical analysis to establish whether areas of high iron deposition were spatially associated with $\mathrm{A} \beta$-containing plaques ${ }^{1}$ this analysis was performed on $60 \mu \mathrm{m}$ resolution XRF maps only. The

\footnotetext{
${ }^{1}$ A small number of isolated pixels included highly localized intense concentrations of calcium. As similar intensity of calcium inclusions were observed when mapping background regions, these pixels were omitted from the analysis. It has since been confirmed with further XRF mapping at the same beamline that although no $\mathrm{XRF}$-detectable trace metals are present in the quartz slides, the Kapton coverslips contain a small number of calcium inclusions. Although areas that coincided with calcium inclusions were automatically omitted from the analysis as a precaution, no other trace metals were detectable in or on the Kapton.
} 

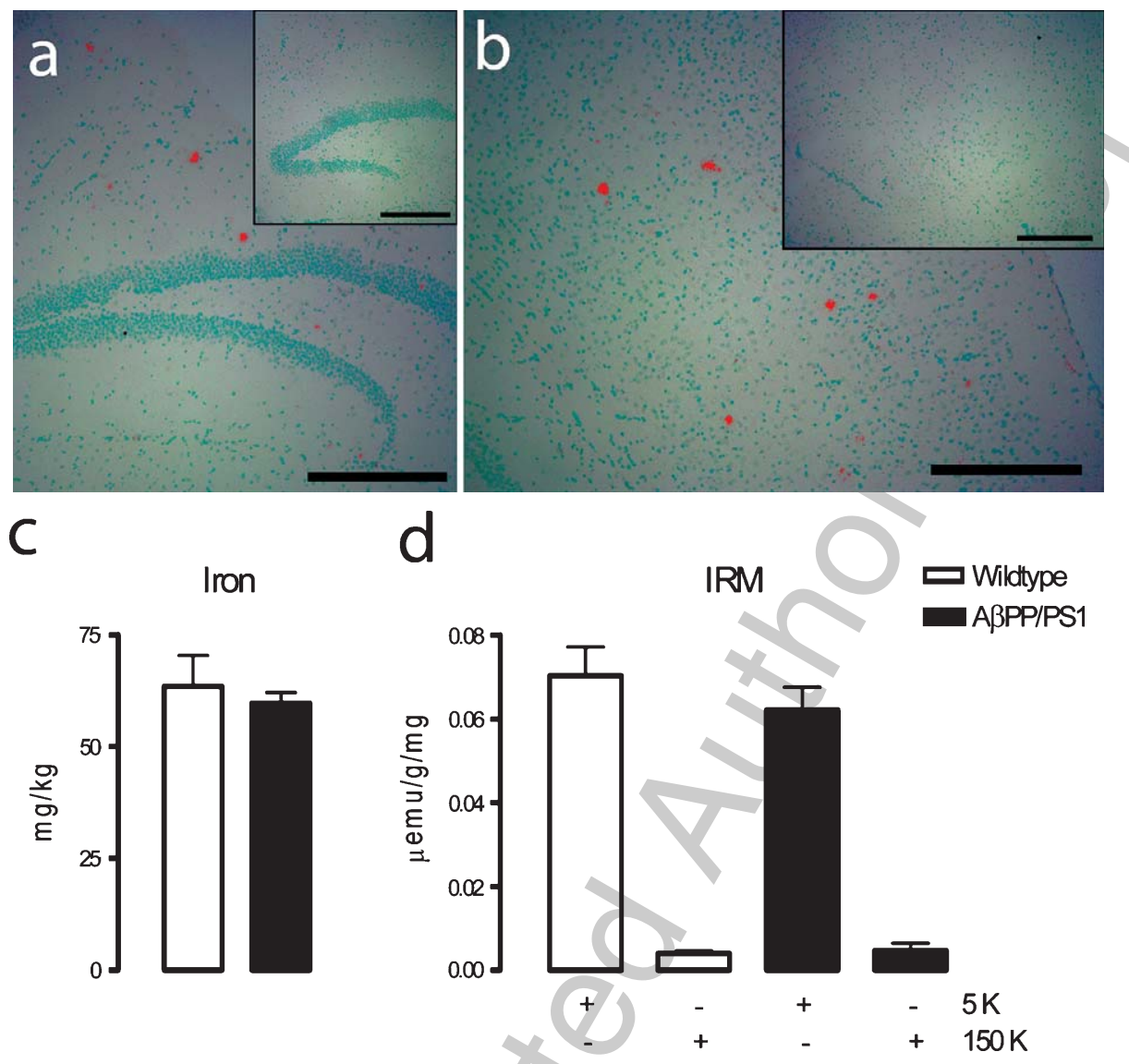

Fig. 1. Brain tissue prepared from A $\beta P P / P S 1$ transgenic and wildtype mice display no difference in total iron content or IRM signal. Representative micrographs confirm Congo red-positive $A \beta$-containing plaques in brain sections prepared from A $\beta P P / P S 1$ transgenic mice in the hippocampus (a) and cortex (b). No plaques were observed in tissue prepared from wildtype mice (insets; $\times 10$ magnification; scale bar $=250 \mu \mathrm{m})$. c) Total iron concentration was similar in tissue prepared from A $\beta P P / P S 1$ transgenic and wildtype mice. IRM measured at $5 \mathrm{~K}$ and $150 \mathrm{~K}$ (d) in tissue prepared from A $\beta P P / P S 1$ transgenic and wildtype mice, following exposure to a magnetic field of 1 Tesla, was similar (IRM data are expressed as $\mu$ emu per grams of iron per mg of brain tissue (dry weight). Data are expressed as means $\pm \operatorname{SEM}(n=4$ or 5$)$.

computed iron map of the CA2 field of the hippocampus is presented (Fig. 4a) with the highlighted area enlarged (b) to allow a comparison with Congo red staining of the same tissue sample (Fig. 4c). The elemental composition in the area co-localized to $A \beta$ containing plaques (labeled 1 in (b) and (c)) was compared with background levels in the tissue (dotted boxed area) and a notable increase in iron $(112 \pm \%)$, but not copper or zinc, was observed (Fig. 4d). $\mu$ XRF spectra and peak analysis of all areas of $A \beta$-containing plaque deposition analyzed in the brain section, including CA1, CA2, and auditory cortex (number of areas sampled $=5$; Fig. 4e), indicated that elevated concentrations of iron in these regions did not consistently co-localize with elevations or decreases in copper and zinc relative to background tissue levels (Fig. 4e). Potassium was found to be a good general indicator of section thickness, and allowed us to confirm that local variations in iron concentration were not attributable to significant variations in sample thickness.

\section{Mixed-valence iron oxides are present in brain tissue associated with high iron deposition}

$\mu \mathrm{XRF}$ microfocus maps identified areas of high iron deposition which were subjected to $\mu$ XANES analysis to determine which iron oxide forms were present. These data were collected in the same session and prior to any histological analysis of the tissue. However, histological analysis of areas subjected to $\mu$ XRF mapping at $5 \mu \mathrm{m}$ and XANES analysis was not possible. An analysis of two areas in the CA2 subfield of the hippocampus is presented (Fig. 5a, b). $\mu$ XANES spectra from the ferritin and magnetite standards are plotted 


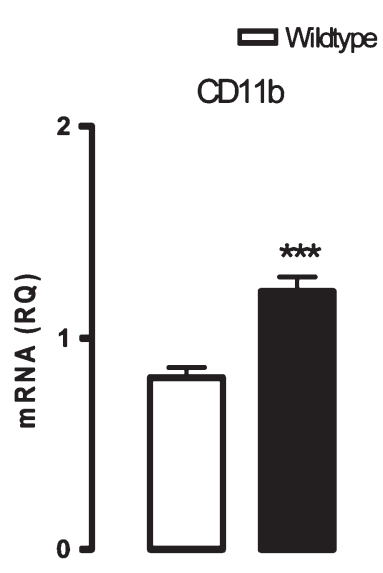

a APPIPS
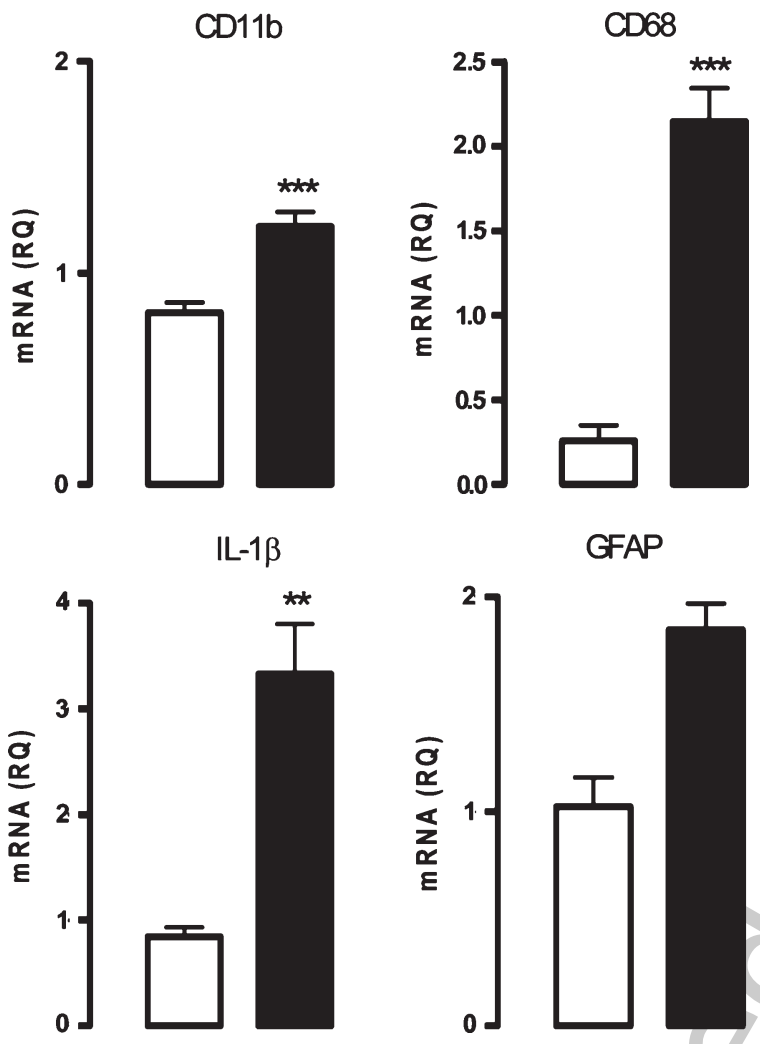

Fig. 2. Markers of microglial and astrocytic activation are increased in brain tissue prepared from A $\beta P P / P S 1$ transgenic, compared with wildtype, mice. CD11b, CD68, IL-1 $\beta$, and GFAP mRNA expression was significantly increased in brain tissue prepared from A $\beta P P / P S 1$ transgenic, compared with wildtype, mice $(* * p<0.01 ; * * * p<0.001$; Student's $t$-test for independent means; CD11b, $t$-value $=4.929$, $\mathrm{df}=7 ;$ CD68, $t$-value $=10.06, \mathrm{df}=7 ; \mathrm{IL}-1 \beta, t$-value $=4.512, \mathrm{df}=7$; GFAP, $t$-value $=4.583, \mathrm{df}=7$;). Data are expressed as a ratio of CD11b, CD68, IL-1 $\beta$, GFAP mRNA: $\beta$-actin mRNA, and are means $\pm \operatorname{SEM}(n=4$ or 5$)$.

of maghaemite or hematite-like oxides. The component proportions indicated by the fit (in this instance, of ferritin and magnetite) enable comparisons of relative, but not absolute, iron oxide concentrations to be made between sites. Identical analysis performed on area of high iron deposition in the dorsal retrosplenial cortex obtained similar results (data not shown). These findings indicate that magnetite may be co-localizing with ferritin in areas of high iron deposition in brain tissue prepared from an A $\beta$ PP/PS1 transgenic mouse. It cannot be confirmed if the regions characterized by $\mu$ XANES co-localized with $A \beta$-containing plaques as these regions were rendered fragile by $5 \mu \mathrm{m}$ resolution $\mu$ XRF-mapping and $\mu$ XANES analysis, and subsequent staining of these local tissue regions was not possible.

\section{DISCUSSION}

We provide evidence indicating the presence of mixed-valence iron oxides, activated microglia, and oxidative stress in a mouse model of $\mathrm{AD}$ at a timepoint where amyloid deposition was modest, suggesting these changes occur relatively early in the time-course of the AD-like pathology replicated by this mouse model.

This is the first demonstration of the presence of magnetite in a mouse model of $\mathrm{AD}$ and it was seen to co-localize with areas of high iron deposition, although it was not possible to determine if these deposits were intracellular or extracellular. The findings indicate that areas of high iron deposition were spatially associated with $A \beta$-containing plaques and this suggests that magnetite was also associated with plaques. However we were unable to directly demonstrate co-localization of magnetite with $A \beta$ deposition due to localized tissue fragility resulting from extended high-resolution $\mu X A S$ analysis. The present data are in agreement with previous findings which identified the presence of magnetite in areas displaying high iron concentration and within $\mathrm{A} \beta$ plaque cores in human $\mathrm{AD}$ tissue $[29,30]$ and, interestingly, redox-active iron deposits have been identified by immunohistochemistry [45] in brain tissue obtained from MCI patients [26]. Optical microscopy accuracy enabled identification of these deposits as being spatially associated with GFAP-positive immunoreactivity, with intracellular and extracellular deposits being observed. Inspection of the published micrographs suggests that their average size is between 5 and $20 \mu \mathrm{m}$ which correlates with the deposits observed in the present study. These 

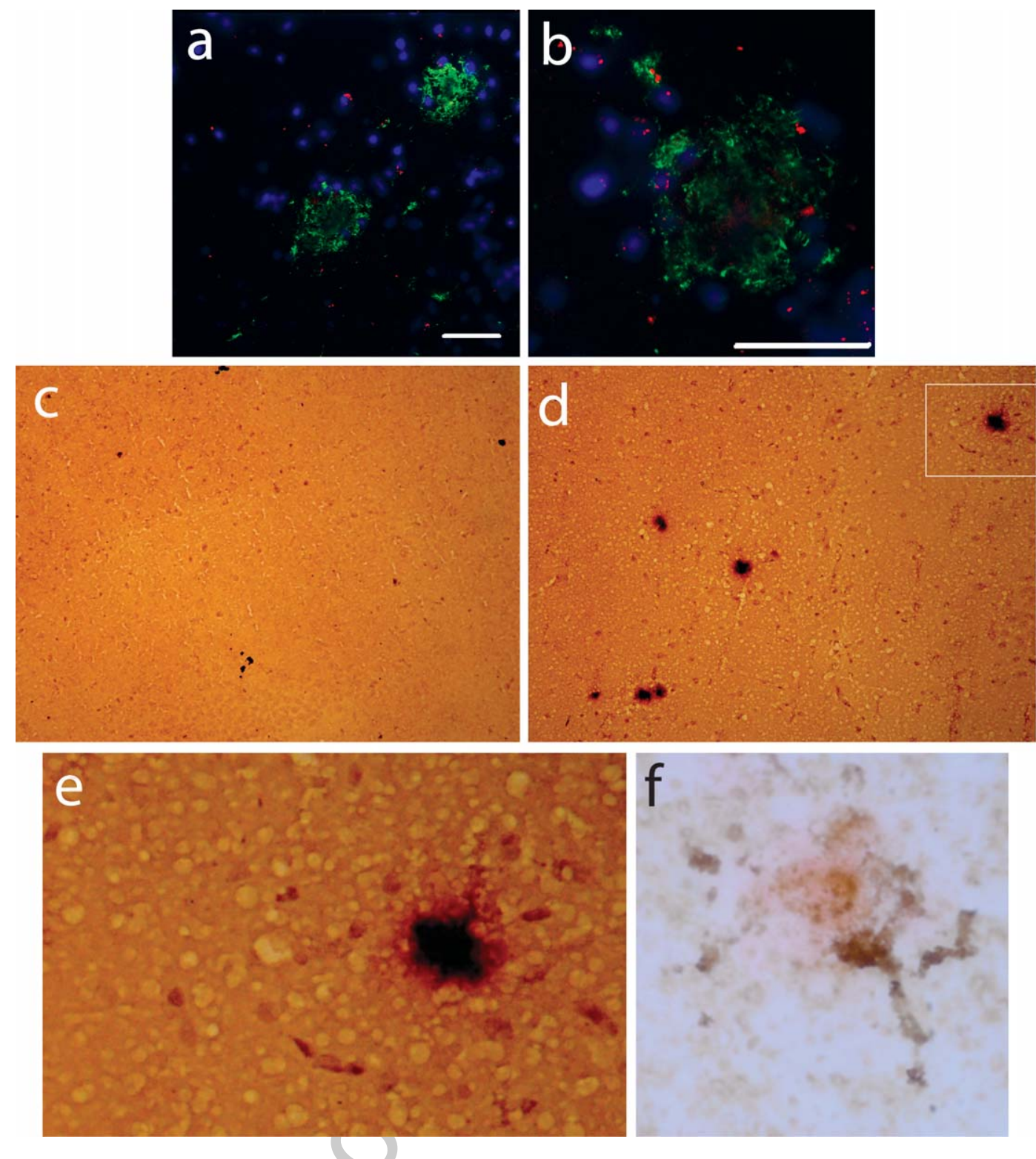

Fig. 3. Increase in markers of microglial activation and oxidative stress proximal to $A \beta$-containing plaques. (a) and (b) $A \beta$-containing immunofluorescent plaques (green), in a brain section prepared from an A $\beta P P / P S 1$ transgenic mouse at 2 magnifications $(a ; \times 40 ; b \times 63$; scale bar $=50 \mu \mathrm{m})$, are encircled by cell nuclei (stained blue with DAPI). MHC II mmunofluorescence (red) is expressed in cells proximal to the plaques. c-e) CD68 staining is markedly increased in a representative brain section prepared from an A $\beta P P / P S 1$ transgenic, (d), and the enlargement of the region of interest, (e), compared with a wildtype, mouse (c; magnification $\times 40)$. f) Increased 8-OHdG immunoreactivity (brown staining) is identified proximal to a Congo red-positive $\mathrm{A} \beta$-containing plaque (pink) in a brain section prepared from an $\mathrm{A} \beta \mathrm{PP} / \mathrm{PS} 1$ transgenic mouse (magnification $\times 40$ ).

deposits may precipitate plaque formation; however, the reported association with astrocytes is puzzling considering the low levels of ferritin observed in astrocytes $[1,26]$. It would be of value in the future to extend this analysis to larger cohorts, in order to establish the extent to which mixed valence iron oxide is formed in regions of amyloid deposition in $\mathrm{AD}$ mouse models. This is significant not only for testing the degree to which isolated in vitro mechanisms are relevant in vivo [34], but also for establishing the extent to which related observations in human ex vivo $\mathrm{AD}$ tissue are replicated in mouse models of $\mathrm{AD}$ [30].

Iron dysregulation is considered to be an early event in the pathogenesis of $\mathrm{AD}$ [26] and some groups have 

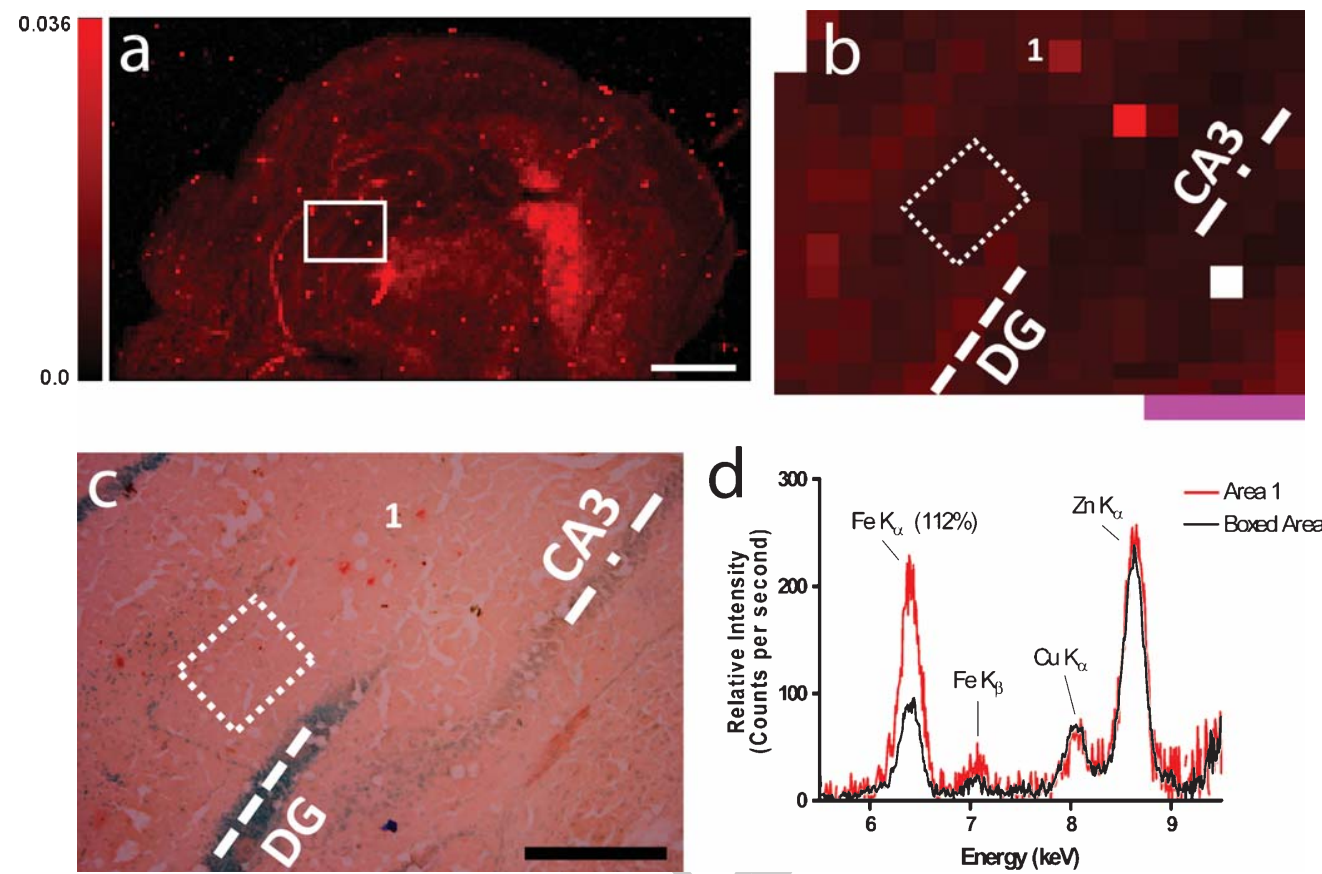

Fluorescence intensity change (\%)

e relative to local background
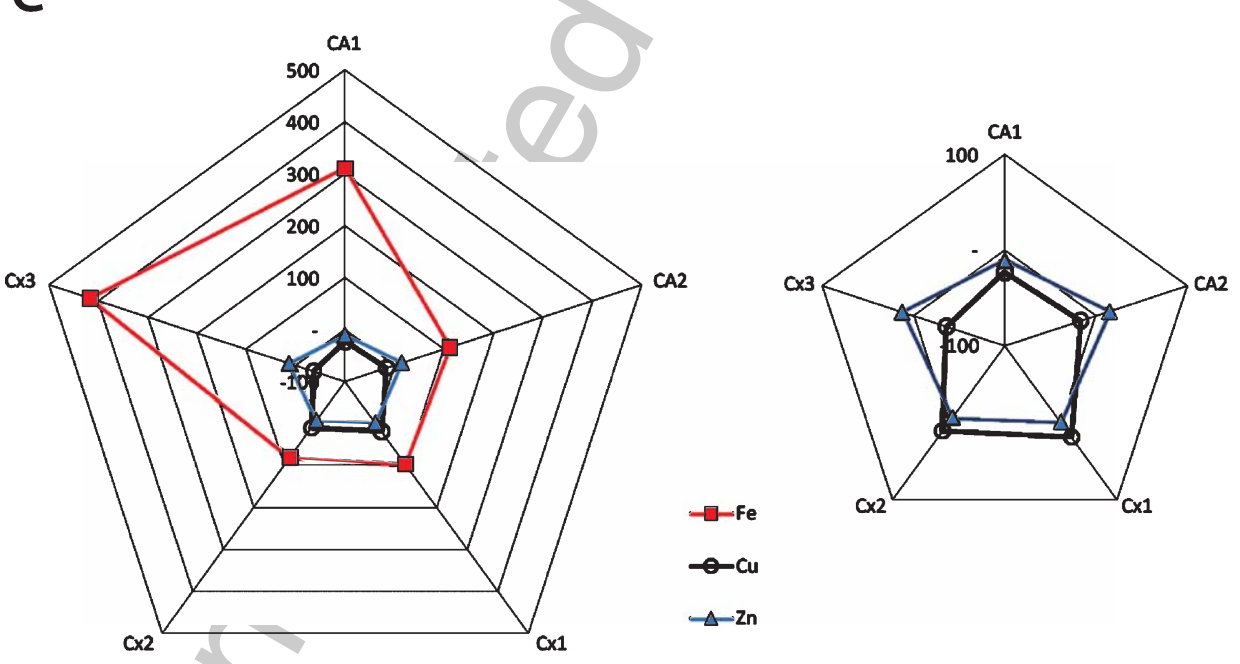

Fig. 4. Areas of high iron concentrations co-localize with $\mathrm{A} \beta$-containing plaques. $\mathrm{mXRF}$ spectral analysis identifies iron deposition in the hippocampus of a brain section prepared from an A PPP/PS1 transgenic mouse. An $\mu$ XRF iron map ( $\mathrm{a}$; scale bar $=1200 \mu \mathrm{m}$, resolution $=60 \times 60 \mu \mathrm{m})$ identifies the area under investigation, an enlarged image $(b ;$ scale bar $=300 \mu \mathrm{m})$ of the inset from (a) identifies an area of high iron deposition (labeled 1) and an area in the CA2 subfield of the hippocampus (boxed area, dotted line). The pixel intensity represents iron fluorescence (normalized to incident beam) and is proportional to total iron present. The white pixels are those exhibiting strong elevations of calcium typical of those identified in the Kapton cover, and are therefore discounted. c) Subsequent Congo red staining of the sample identified A $\beta$-containing plaques and the area marked 1 corresponds with that marked 1 in (b), showing spatial correlation of $A \beta$-containing plaques with high iron concentration $(\times 10$ magnification; scale bar $=200 \mu \mathrm{m})$. To aid effective comparison between $(b)$ and $(c)$ the lateral blade of the dentate gyrus (DG) and the pyramidal layer of the CA3 field (CA3) are identified on both. d) The $\mu$ XRF spectra analysis displays the change in the fluorescence intensity of several elements in area 1 relative to the boxed area. Spectra associated with the Ko edge for Iron (Fe), Copper $(\mathrm{Cu})$, and $\mathrm{Zinc}$ (Zn) are shown (with the $\mathrm{K} \beta$ edge for iron also identified). e) The fluorescence intensity change (relative to a local background) for all areas of tissue, with $\mathrm{A} \beta$-containing plaque deposition, analyzed; $\mathrm{Fe}, \mathrm{Cu}$, and $\mathrm{Zn}$ changes are shown ( $n=5$; areas analyzed include hippocampal (CA2 and CA3 subfield areas) and cortical ( $\mathrm{Cx} 1, \mathrm{Cx} 2$ and $\mathrm{Cx} 3$ ) amyloid deposits). A magnified version of the $\mathrm{Cu}$ and $\mathrm{Zn}$ portion of the radar plot is also provided. The radar plot center represents a 100\% decrease in fluorescence intensity, with the radar plotlines away from the center indicating a $0-500 \%$ increase in fluorescence in 100\% steps (relative to a local background in all instances). 

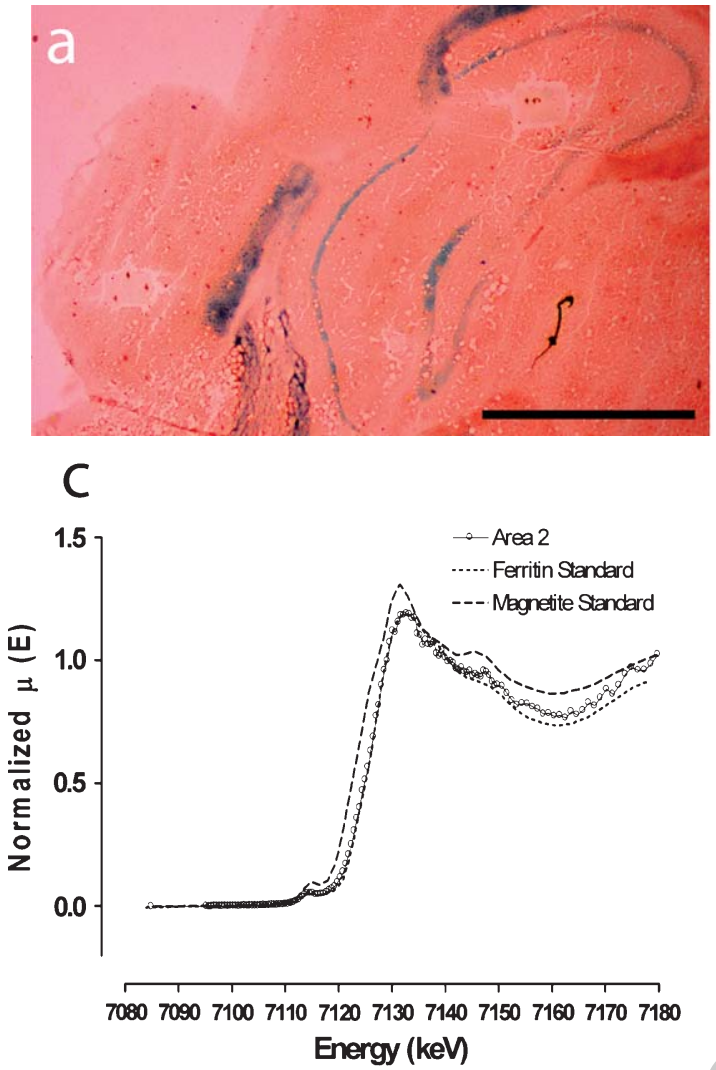
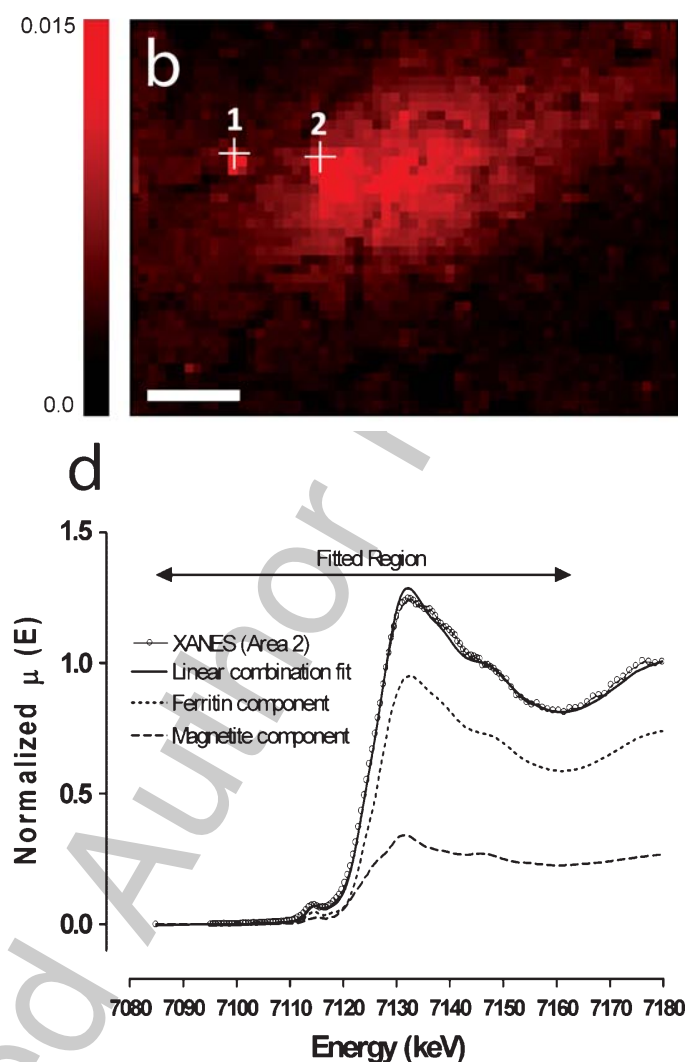

e

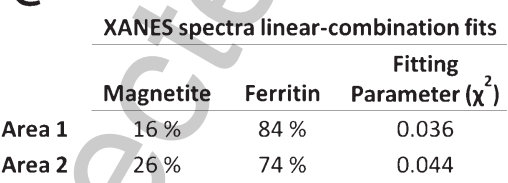

Fig. 5. XANES analysis indicates the presence of mixed valence iron oxides in areas of high iron deposition. Microfocus XAS analysis was undertaken in areas of high iron deposition in the CA2 subfield of the hippocampus of a brain section prepared from an A $3 P P / P S 1$ transgenic mouse. Composite Congo red and toludine blue light microscopy (a), microfocus iron $\mu$ XRF map (b), XANES spectra for Area 2 and magnetite and ferritin XANES standards (c), XANES spectra linear combination plot for Area 2 are presented (d) and results for Area 1 and 2 shown in (e). The microfocus iron map (b) location is identified in (a) and the areas chosen for XANES analysis labeled in (b). a) Light micrographs in composite image were taken at $\times 2.5$ magnification, scale bar $=1200 \mu \mathrm{m}$. b) Microfocus map pixel resolution $=5 \mu \mathrm{m}$; scale bar $=50 \mu \mathrm{m}$. The pixel intensity represents iron fluorescence (normalized to incident beam) and is proportional to total iron present. (inset; micrograph taken at $\times 20$ magnification, scale bar $=100 \mu \mathrm{m}$ ).

suggested that it may actually trigger aspects of $\mathrm{AD}$ pathology $[13,46,47]$. The evidence indicates that deficits in iron regulation may lead to mitochondrial dysfunction which is identified as an early change in $\mathrm{AD}$ [48] and it is interesting that expression of the haemochromatosis protein, which is a hallmark of iron-overload disorders [49], is upregulated in reactive astrocytes and neurons in the AD brain [50].

Whereas our data show that iron was associated with $A \beta$-containing plaques, no association for copper or zinc was observed in this study of a transgenic mouse model, however, several groups have reported increases in copper and zinc levels in $\mathrm{A} \beta$-plaques in human tissue from end-stage $\mathrm{AD}$ patients [22, 23]. No difference in brain tissue concentrations of iron, copper, or zinc were found in the present study. However at 18 months of age, a female mouse model of $\mathrm{AD}$ was reported to display a reduction in copper, an increase in iron, and no change in zinc, suggesting that metal ion concentrations may change as pathology progresses [51]. More recent studies have identified a link between zinc transporter proteins and $\mathrm{AD}$; aberrant patterns have been identified in MCI brain tissue [52] and the presence of zinc transporter proteins has been 
identified in $A \beta$-containing plaques in postmortem brain tissue prepared from AD patients [53]. Although changes in metal concentration may occur in late-stage pathology [54], the evidence from the literature indicates that the dysregulation of iron, and possibly zinc, precede such changes [26,55]. Although in this study there are no clear differences in the bulk iron concentration and magnetic properties of the wild type and A $\beta P P / P S 1$ brain tissue, the synchrotron $\mu$ XAS analysis has enabled the location and identification of magnetite in regions exhibiting focal increases in iron deposition, highlighting the advantage of examining iron dysregulation at a microscopic scale.

The presence of magnetite suggests dysregulation of normal iron storage and we show that $8-\mathrm{OHdG}$ immunoreactivity, which is indicative of oxidative stress, was increased in tissue proximal to $A \beta$ containing plaques. There are several reports of lipid peroxidation occurring prior to amyloid plaque formation [56], while several others confirm oxidative stress damage is associated with plaques [57]. Oxidative stress is also known to upregulate $A \beta P P$ and $\beta$ and $\gamma$-secretases [58] and the possibility exists that iron may directly influence plaque formation by modulating A $\beta P P$ processing. Previous reports indicating magnetite association with $A \beta$-containing plaques has led some groups to suggest $A \beta$ redox chemistry may be ongoing within the plaque itself [30]. Interestingly iron, but not zinc, accelerates $A \beta_{42}$ beta-pleated sheet formation in vitro [59] and the presence of aggregating $\mathrm{A} \beta_{42}$ has been shown in vitro to stabilize a proportion of reactive ferrous iron that in the absence of the $A \beta_{42}$ would auto-oxidize to the more stable ferric form, creating an environment that may lead to the generation of excess radical species [34]. It has also been suggested that redox active iron may mediate the neurotoxicity of $A \beta$ [60], and several reports suggest interactions between iron and $\mathrm{A} \beta$ may ultimately be neuroprotective if they lead to redox-silencing of iron [61-63]. We observed that the increase in oxidative stress was associated with evidence of activated microglia, identified by increases in expression of $\mathrm{CD} 11 \mathrm{~b}$ and CD68 mRNA levels and increased CD68 and MHC II immunoreactivity. These findings are consistent with the well-accepted view that activated microglia are primarily responsible for producing oxygen radicals [64] and while the mixed-valence iron oxide deposits may be indicative of disrupted iron handling, and locally increased concentrations of ferrous iron, there is no direct evidence to link the resulting magnetite deposits identified in this study with oxidative damage. The increase in CD68, which is a marker of lysosomal activity may indicate that microglia are phagocytic [65] but current literature suggests that minimal phagocytosis of plaques occurs [20]. It is possible the CD68-positive cells are involved in the phagocytosis of cellular debris adjacent to $A \beta$-containing plaques or perhaps smaller $A \beta$ deposits.

Activated microglia are considered to be the primary source of inflammatory cytokines, although release from astrocytes also occurs [66]. Here we show that the increase in markers of microglial activation is accompanied by increased GFAP mRNA expression, which is an indicator of astrocytosis, and with a marked increase in IL-1 $1 \beta$ mRNA in tissue prepared from A $\beta P P / P S 1$ transgenic mice. This supports previous work identifying astrocyte activation in mouse models of $\mathrm{AD}$ [44] and indicating a close relationship between proinflammatory cytokines and plaque deposition [67]. However the role of IL-1 $\beta$ in AD pathology is complex. For example, it has been reported that overexpression of IL-1 $\beta$ leads to reduced plaque deposition in a mouse model of AD [68] but that IL-1 $\beta$ increases A $\beta P P$ synthesis and processing [69] and increases in proinflammatory markers, including IL- $1 \beta$, are found in the $\mathrm{AD}$ brain in patients from different disease stages [70].

We set out to assess whether the early stages of $\mathrm{A} \beta$ plaque deposition were associated with evidence of changes in the handling of iron by cells. Our findings suggest the presence of deposits of a mixedvalence iron oxide proximal to $A \beta$-containing plaques in A $\beta P P / P S 1$ transgenic mice. The co-localization of magnetite and deposits containing normal ferrihydritelike ferritin cores is consistent with former studies in human tissues indicating altered iron storage in $\mathrm{AD}$ ferritin, $\mathrm{AD}$ plaques, and plaque-rich $\mathrm{AD}$ tissues. Interestingly this observation in the A $\beta P P / P S 1$ transgenic mouse was coupled with evidence of microglial activation accompanied by evidence of oxidative stress. We propose that this may contribute to the dysregulation in iron handling and may lead to progression of pathology.

\section{ACKNOWLEDGMENTS}

This work was carried out with the support of Diamond Light Source. The Quantum Design MPMS magnetometer used in this research was obtained, through the Science City Advanced Materials project: Creating and Characterising Next Generation Advanced Materials project, with support from Advantage West Midlands (AWM) and part funded by the European Regional Development Fund 
(ERDF). JJG was funded by the Health Research Board (Ireland) and Science Foundation Ireland.

Authors' disclosures available online (http://www.jalz.com/disclosures/view.php?id=983).

\section{REFERENCES}

[1] Zecca L, Youdim MB, Riederer P, Connor JR, Crichton RR (2004) Iron, brain ageing and neurodegenerative disorders. Nat Rev Neurosci 5, 863-873.

[2] Aisen P, Enns C, Wessling-Resnick M (2001) Chemistry and biology of eukaryotic iron metabolism. Int J Biochem Cell Biol 33, 940-959.

[3] Jefferies WA, Brandon MR, Hunt SV, Williams AF, Gatter KC, Mason DY (1984) Transferrin receptor on endothelium of brain capillaries. Nature 312, 162-163.

[4] Burdo JR, Connor JR (2003) Brain iron uptake and homeostatic mechanisms: An overview. Biometals 16, 63-75.

[5] Campuzano V, Montermini L, Molto MD, Pianese L, Cossee M, Cavalcanti F, Monros E, Rodius F, Duclos F, Monticelli A, Zara F, Canizares J, Koutnikova H, Bidichandani SI, Gellera C, Brice A, Trouillas P, De Michele G, Filla A, De Frutos R, Palau F, Patel PI, Di Donato S, Mandel JL, Cocozza S, Koenig M, Pandolfo M (1996) Friedreich's ataxia: Autosomal recessive disease caused by an intronic GAA triplet repeat expansion. Science 271, 1423-1427.

[6] Thompson PM, Hua X, Leow AD, Lee S, Klunder AD, Toga AW, Lepore N, Chou YY, Brun C, Chiang MC, Barysheva M, Jack CR, Bernstein MA, Britson PJ, Ward CP, Whitwell JL, Borowski B, Fleisher AS, Fox NC, Boyes RG, Barnes J, Harvey D, Kornak J, Schuff N, Boreta L, Alexander GE, Weiner MW, Initi AsDN (2008) 3D characterization of brain atrophy in Alzheimer's disease and mild cognitive impairment using tensor-based morphometry. Neuroimage 41, 19-34.

[7] Selkoe DJ (1994) Alzheimer's disease: A central role for amyloid. J Neuropathol Exp Neurol 53, 438-447.

[8] Walsh DM, Klyubin I, Fadeeva JV, Cullen WK, Anwyl R, Wolfe MS, Rowan MJ, Selkoe DJ (2002) Naturally secreted oligomers of amyloid beta protein potently inhibit hippocampal long-term potentiation in vivo. Nature 416, 535539.

[9] Wang X, Su B, Fujioka H, Zhu X (2008) Dynamin-like protein 1 reduction underlies mitochondrial morphology and distribution abnormalities in fibroblasts from sporadic Alzheimer's disease patients. Am J Pathol 173, 470-482.

[10] Stokin GB, Lillo C, Falzone TL, Brusch RG, Rockenstein E, Mount SL, Raman R, Davies P, Masliah E, Williams DS, Goldstein LS (2005) Axonopathy and transport deficits early in the pathogenesis of Alzheimer's disease. Science 307, 1282-1288.

[11] Scheff SW, Price DA, Schmitt FA, DeKosky ST, Mufson EJ (2007) Synaptic alterations in CA1 in mild Alzheimer disease and mild cognitive impairment. Neurology 68, 1501-1508.

[12] Pappolla MA, Chyan YJ, Omar RA, Hsiao K, Perry G, Smith MA, Bozner P (1998) Evidence of oxidative stress and in vivo neurotoxicity of beta-amyloid in a transgenic mouse model of Alzheimer's disease: A chronic oxidative paradigm for testing antioxidant therapies in vivo. Am J Pathol 152, 871-877.

[13] Smith MA, Perry G, Pryor WA (2002) Causes and consequences of oxidative stress in Alzheimer's disease. Free Radic Biol Med 32, 1049.

[14] Dickson DW, Lee SC, Mattiace LA, Yen SH, Brosnan C (1993) Microglia and cytokines in neurological disease, with special reference to AIDS and Alzheimer's disease. Glia 7, $75-83$.

[15] Griffin WS, Stanley LC, Ling C, White L, MacLeod V, Perrot LJ, White CL, 3rd, Araoz C (1989) Brain interleukin 1 and S-100 immunoreactivity are elevated in Down syndrome and Alzheimer disease. Proc Natl Acad Sci U S A 86, 7611-7615.

[16] Nunomura A, Perry G, Aliev G, Hirai K, Takeda A, Balraj EK, Jones PK, Ghanbari H, Wataya T, Shimohama S, Chiba S, Atwood CS, Petersen RB, Smith MA (2001) Oxidative damage is the earliest event in Alzheimer disease. J Neuropathol Exp Neurol 60, 759-767.

[17] Beal MF (2005) Oxidative damage as an early marker of Alzheimer's disease and mild cognitive impairment. Neurobiol Aging 26, 585-586.

[18] Wang Q, Rowan MJ, Anwyl R (2004) Beta-amyloid-mediated inhibition of NMDA receptor-dependent long-term potentiation induction involves activation of microglia and stimulation of inducible nitric oxide synthase and superoxide. J Neurosci 24, 6049-6056.

[19] Lue LF, Brachova L, Civin WH, Rogers J (1996) Inflammation, A beta deposition, and neurofibrillary tangle formation as correlates of Alzheimer's disease neurodegeneration. J Neuropathol Exp Neurol 55, 1083-1088.

[20] Meyer-Luehmann M, Spires-Jones TL, Prada C, GarciaAlloza M, de Calignon A, Rozkalne A, Koenigsknecht-Talboo J, Holtzman DM, Bacskai BJ, Hyman BT (2008) Rapid appearance and local toxicity of amyloid-beta plaques in a mouse model of Alzheimer's disease. Nature 451, 720-724.

[21] Hallgren B, Sourander P (1958) The effect of age on the nonhaemin iron in the human brain. $J$ Neurochem 3, 41-51.

[22] Lovell MA, Robertson JD, Teesdale WJ, Campbell JL, Markesbery WR (1998) Copper, iron and zinc in Alzheimer's disease senile plaques. J Neurol Sci 158, 47-52.

[23] Miller LM, Wang Q, Telivala TP, Smith RJ, Lanzirotti A, Miklossy J (2006) Synchrotron-based infrared and X-ray imaging shows focalized accumulation of $\mathrm{Cu}$ and $\mathrm{Zn}$ co-localized with beta-amyloid deposits in Alzheimer's disease. J Struct Biol 155, 30-37.

[24] Collingwood J, Dobson J (2006) Mapping and characterization of iron compounds in Alzheimer's tissue. J Alzheimers Dis 10, 215-222.

[25] Connor JR, Menzies SL, St Martin SM, Mufson EJ (1992) A histochemical study of iron, transferrin, and ferritin in Alzheimer's diseased brains. J Neurosci Res 31, 75-83.

[26] Smith MA, Zhu XW, Tabaton M, Liu G, McKeel DW, Cohen ML, Wang XL, Siedlak SL, Dwyer BE, Hayashi T, Nakamura M, Nunomura A, Perry G (2010) Increased iron and free radical generation in preclinical Alzheimer disease and mild cognitive impairment. J Alzheimers Dis 19, 363-372.

[27] Kirschvink JL, Kobayashikirschvink A, Woodford BJ (1992) Magnetite biomineralization in the human brain. Proc Natl Acad Sci U S A 89, 7683-7687.

[28] Hautot D, Pankhurst QA, Khan N, Dobson J (2003) Preliminary evaluation of nanoscale biogenic magnetite in Alzheimer's disease brain tissue. Proc R Soc Lond 270, S62S64.

[29] Collingwood JF, Mikhaylova A, Davidson M, Batich C, Streit WJ, Terry J, Dobson J (2005) In situ characterization and mapping of iron compounds in Alzheimer's disease tissue. J Alzheimers Dis 7, 267-272.

[30] Collingwood JF, Chong RK, Kasama T, Cervera-Gontard L, Dunin-Borkowski RE, Perry G, Posfai M, Siedlak SL, Simpson ET, Smith MA, Dobson J (2008) Three-dimensional tomographic imaging and characterization of iron compounds 
within Alzheimer's plaque core material. J Alzheimers Dis 14, 235-245.

[31] Quintana C, Cowley JM, Marhic C (2004) Electron nanodiffraction and high-resolution electron microscopy studies of the structure and composition of physiological and pathological ferritin. J Struct Biol 147, 166-178.

[32] Dobson J (2004) Magnetic iron compounds in neurological disorders. Ann N Y Acad Sci 1012, 183-192.

[33] Mikhaylova A, Davidson M, Toastmann H, Channell JET, Guyodo Y, Batich C, Dobson J (2005) Detection, identification and mapping of iron anomalies in brain tissue using X-ray absorption spectroscopy. $J R$ Soc Interface 2 , 33-37.

[34] Khan A, Dobson JP, Exley C (2006) Redox cycling of iron by Abeta42. Free Radic Biol Med 40, 557-569.

[35] Wilcock DM, Gordon MN, Morgan D (2006) Quantification of cerebral amyloid angiopathy and parenchymal amyloid plaques with Congo red histochemical stain. Nat Protoc 1, 1591-1595.

[36] Lyons A, Griffin RJ, Costelloe CE, Clarke RM, Lynch MA (2007) IL-4 attenuates the neuroinflammation induced by amyloid-beta in vivo and in vitro. J Neurochem 101, 771781 .

[37] Downer EJ, Cowley TR, Lyons A, Mills KH, Berezin V, Bock E, Lynch MA (2010) A novel anti-inflammatory role of NCAM-derived mimetic peptide, FGL. Neurobiol Aging 31, 118-128.

[38] Hautot D, Pankhurst Q, Dobson J (2005) Superconducting quantum interference device measurements of dilute magnetic materials in biological samples. Re Sc Instrum 76.

[39] Mosselmans JFW, Quinn PD, Dent AJ, Cavill SA, Moreno SD, Peach A, Leicester PJ, Keylock SJ, Gregory SR, Atkinson KD, Rosell JR (2009) I18 - the microfocus spectroscopy beamline at the Diamond Light Source. J Synchrotron Radiat 16, 818-824.

[40] Solé VA, Papillon E, Cotte M, Walter P, Susini J (2007) A multiplatform code for the analysis of energy-dispersive $\mathrm{X}$ ray fluorescence spectra. Spectrochim Acta B 62, 63-68.

[41] Ravel B, Newville M (2005) ATHENA, ARTEMIS, HEPHAESTUS: Data analysis for X-ray absorption spectroscopy using IFEFFIT. $J$ Synchrotron Radiat 12, 537-541.

[42] Ruan L, Kang Z, Pei G, Le Y (2009) Amyloid deposition and inflammation in APPswe/PS1dE9 mouse model of Alzheimer's disease. Curr Alzheimer Res 6, 531-540.

[43] Garcia-Alloza M, Robbins EM, Zhang-Nunes SX, Purcell SM, Betensky RA, Raju S, Prada C, Greenberg SM, Bacskai BJ, Frosch MP (2006) Characterization of amyloid deposition in the APPswe/PS1dE9 mouse model of Alzheimer disease. Neurobiol Dis 24, 516-524.

[44] Gordon MN, Holcomb LA, Jantzen PT, DiCarlo G, Wilcock D, Boyett KW, Connor K, Melachrino J, O'Callaghan JP, Morgan D (2002) Time course of the development of Alzheimer-like pathology in the doubly transgenic PS1+APP mouse. Exp Neurol 173, 183-195.

[45] Sayre LM, Perry G, Harris PL, Liu Y, Schubert KA, Smith MA (2000) In situ oxidative catalysis by neurofibrillary tangles and senile plaques in Alzheimer's disease: A central role for bound transition metals. J Neurochem 74, 270-279.

[46] Gerlach M, Ben-Shachar D, Riederer P, Youdim MB (1994) Altered brain metabolism of iron as a cause of neurodegenerative diseases? J. Neurochem 63, 793-807.

[47] Leskovjan AC, Kretlow A, Lanzirotti A, Barrea R, Vogt S, Miller LM (2011) Increased brain iron coincides with early plaque formation in a mouse model of Alzheimer's disease. Neuroimage 55, 32-38.
[48] Hirai K, Aliev G, Nunomura A, Fujioka H, Russell RL, Atwood CS, Johnson AB, Kress Y, Vinters HV, Tabaton M, Shimohama S, Cash AD, Siedlak SL, Harris PL, Jones PK, Petersen RB, Perry G, Smith MA (2001) Mitochondrial abnormalities in Alzheimer's disease. J Neurosci 21, 3017-3023.

[49] Merryweather-Clarke AT, Pointon JJ, Shearman JD, Robson KJ (1997) Global prevalence of putative haemochromatosis mutations. J Med Genet 34, 275-278.

[50] Connor JR, Milward EA, Moalem S, Sampietro M, Boyer P, Percy ME, Vergani C, Scott RJ, Chorney M (2001) Is hemochromatosis a risk factor for Alzheimer's disease? $J$ Alzheimers Dis 3, 471-477.

[51] Maynard CJ, Cappai R, Volitakis I, Cherny RA, White AR, Beyreuther K, Masters CL, Bush AI, Li QX (2002) Overexpression of Alzheimer's disease amyloid-beta opposes the age-dependent elevations of brain copper and iron. $J$ Biol Chem 277, 44670-44676.

[52] Lyubartseva G, Smith JL, Markesbery WR, Lovell MA (2010) Alterations of zinc transporter proteins ZnT-1, ZnT-4 and ZnT6 in preclinical Alzheimer's disease brain. Brain Pathol 20, 343-350.

[53] Zhang LH, Wang X, Stoltenberg M, Danscher G, Huang L, Wang ZY (2008) Abundant expression of zinc transporters in the amyloid plaques of Alzheimer's disease brain. Brain Res Bull 77, 55-60.

[54] Deibel MA, Ehmann WD, Markesbery WR (1996) Copper, iron, and zinc imbalances in severely degenerated brain regions in Alzheimer's disease: Possible relation to oxidative stress. J Neurol Sci 143, 137-142.

[55] Lovell MA, Smith JL, Xiong S, Markesbery WR (2005) Alterations in zinc transporter protein-1 (ZnT-1) in the brain of subjects with mild cognitive impairment, early, and late-stage Alzheimer's disease. Neurotox Res 7, 265-271.

[56] Pratico D, Uryu K, Leight S, Trojanoswki JQ, Lee VM (2001) Increased lipid peroxidation precedes amyloid plaque formation in an animal model of Alzheimer amyloidosis. J Neurosci 21, 4183-4187.

[57] Smith MA, Hirai K, Hsiao K, Pappolla MA, Harris PL, Siedlak SL, Tabaton M, Perry G (1998) Amyloid-beta deposition in Alzheimer transgenic mice is associated with oxidative stress. J Neurochem 70, 2212-2215.

[58] Tamagno E, Guglielmotto M, Aragno M, Borghi R, Autelli R, Giliberto L, Muraca G, Danni O, Zhu X, Smith MA, Perry G, Jo DG, Mattson MP, Tabaton M (2008) Oxidative stress activates a positive feedback between the gamma- and betasecretase cleavages of the beta-amyloid precursor protein. $J$ Neurochem 104, 683-695.

[59] House E, Collingwood J, Khan A, Korchazkina O, Berthon G, Exley C (2004) Aluminium, iron, zinc and copper influence the in vitro formation of amyloid fibrils of Abeta(42) in a manner which may have consequences for metal chelation therapy in Alzheimer's disease. J Alzheimers Dis 6, 291-301.

[60] Rottkamp CA, Raina AK, Zhu X, Gaier E, Bush AI, Atwood CS, Chevion M, Perry G, Smith MA (2001) Redox-active iron mediates amyloid-beta toxicity. Free Radic Biol Med 30, 447-450.

[61] Rogers JT, Randall JD, Cahill CM, Eder PS, Huang X, Gunshin H, Leiter L, McPhee J, Sarang SS, Utsuki T, Greig NH, Lahiri DK, Tanzi RE, Bush AI, Giordano T, Gullans SR (2002) An iron-responsive element type II in the $5^{\prime}$-untranslated region of the Alzheimer's amyloid precursor protein transcript. J Biol Chem 277, 45518-45528.

[62] Bishop GM, Robinson SR (2004) The amyloid paradox: Amyloid-beta-metal complexes can be neurotoxic and neuroprotective. Brain Pathol 14, 448-452. 
[63] Nakamura M, Shishido N, Nunomura A, Smith MA, Perry G, Hayashi Y, Nakayama K, Hayashi T (2007) Three histidine residues of amyloid-beta peptide control the redox activity of copper and iron. Biochemistry (Mosc) 46, 12737-12743.

[64] Banati RB, Gehrmann J, Schubert P, Kreutzberg GW (1993) Cytotoxicity of microglia. Glia 7, 111-118.

[65] Lynch MA (2009) The multifaceted profile of activated microglia. Mol Neurobiol 40, 139-156.

[66] Moynagh PN (2005) The interleukin-1 signalling pathway in astrocytes: A key contributor to inflammation in the brain. J Anat 207, 265-269.

[67] Mrak RE, Griffin WS (2001) Interleukin-1, neuroinflammation, and Alzheimer's disease. Neurobiol Aging 22, 903-908.
[68] Shaftel SS, Kyrkanides S, Olschowka JA, Miller JN, Johnson RE, rsquo O, Banion MK (2007) Sustained hippocampal IL-1 beta overexpression mediates chronic neuroinflammation and ameliorates Alzheimer plaque pathology. J Clin Invest 117, 1595-1604.

[69] Forloni G, Demicheli F, Giorgi S, Bendotti C, Angeretti N (1992) Expression of amyloid precursor protein mRNAs in endothelial, neuronal and glial cells: Modulation by interleukin-1. Brain Res Mol Brain Res 16, 128-134.

[70] Griffin WS, Sheng JG, Roberts GW, Mrak RE (1995) Interleukin-1 expression in different plaque types in Alzheimer's disease: Significance in plaque evolution. $\mathrm{J} \mathrm{Neu-}$ ropathol Exp Neurol 54, 276-281. 